https://doi.org/10.52058/2786-4952 -2022-1(6)-53-62

Бойко Ольга Петрівна доктор філософських наук, професор, професор кафедри психології, політології та соціокультурних технологій, Сумський державний університет, вул. Римського-Корсакова, 2, м. Суми, 40000, тел.: (050) 882-05-15, https://orcid.org/0000-0001-8484-6625

Повалій Тетяна Леонідівна кандидат педагогічних наук, старший викладач кафедри психології, політології та соціокультурних технологій, Сумський державний університет, вул. Римського-Корсакова, 2, м. Суми, 40000, тел.: (066) 484-78-95, https://orcid.org/0000-0001-5821-9775

Синах Андрій Олександрович кандидат філософських наук, доцент, доцент кафедри психології, політології та соціокультурних технологій, Сумський державний університет, вул. Римського-Корсакова, 2, м. Суми, 40000, тел.: (050) 518-63-18, https://orcid.org/0000-0002-8699-3781

Матковський Олександр Миколайович провідний концертмейстер кафедри хореографії та музично-інструментального виконавства, Сумський державний педагогічний університет імені А. С. Макаренка, вул. Роменська, 87, м. Суми, 40000, тел.: (050) 807-06-93, https://orcid.org/0000-0001-7814-7991

\title{
ПРАКТИКА ОРГАНІЗАЦІЇ ЛІТНЬОГО ТАНЦЮВАЛЬНОГО ТАБОРУ: ПСИХОЛОГО-ПЕДАГОГІЧНИЙ АСПЕКТ
}

Анотація. У статті висвітлюються особливості організації літнього танцювального табору. В умовах комп'ютерізації та зменшення рухової активності дітей, надзвичайно важливого значення набуває організація їх активного літнього відпочинку. 3 огляду на це, саме танцювальний табір набирає все більше і більше популярності, оскільки він є таким соціальним інститутом, який сприяє збагаченню у дітей рухового досвіду, вдосконаленню ïx моторики, розвитку активних розумових дій в процесі виконання фізичних вправ тощо.

Мета дослідження полягає у висвітленні особливостей організації літнього танцювального табору. Важливим результатом дослідження $є$ те, що було конкретизовано та уточнено термін «танцювальний табір» яке розуміємо як тимчасовий заклад додаткової освіти для дітей і підлітків, зміст діяльності якого переважно побудовано на оволодінні практичними навичками у різних танцювальних напрямках. Зазначено, що активний відпочинок у таборі вбирає в себе багато переваг, зокрема таких як: системотворчу роботу, міжособистісні стосунки, активну участь у творчій діяльності, інтенсивність роботи, 
комплексний підхід. Подано перелік можливих форм роботи в літньому танцювальному таборі, до яких відносяться наступні: вечори, ритмічні ігри, колективно-творчі справи, багаття, конкурси, танцювальні майстер-класи та тренінги. З'ясовано основні періоди діяльності літнього танцювального табору, а саме: підготовчий, організаційний, основний, заключний та посттабірний періоди. Проаналізовано декілька розважальних програм літніх танцювальних таборів. Результати аналізу представлено у вигляді переліку основних форм діяльності, до яких відносяться: роздача фірмових футболок табору, майстер-класи 3 різних танцювальних напрямів, вечірні розважальні програми, зйомки відеоролику з усіма моментами танцювальної зміни, вивчення та презентація танцювального флешмобу, фан-зустрічі 3 навідомішими хореографами міста, спортивна програма та змагання 3 усіх видів спорту.

Ключові слова: танцювальний табір, хореограф, майстер-клас, флешмоб, розважальна програма.

Boyko Olga Petrivna DSc, Professor, Professor of the Department of Psychology, Political and Socio-Cultural Technologies, Sumy State University, Rimsky-Korsakov St., 2, Sumy, 40000, tel.: (050) 882-05-15, https://orcid.org/0000-0001-8484-6625

Povalii Tetiana Leonidivna $\mathrm{PhD}$, Senior Lecturer of the Department of Psychology, Political and Socio-Cultural Technologies, Sumy State University, Rimsky-Korsakov St., 2, Sumy, 40000, tel.: (066) 484-78-95, https://orcid.org/0000-0001-5821-9775

Synakh Andrii Alexandrovich PhD, Assoc. Professor, Assoc. Professor of the Department of Psychology, Political and Socio-Cultural Technologies, Sumy State University, 40000, Sumy, Rimsky-Korsakov St., 2, tel.: (050) 518-63-18, https://orcid.org/0000-0002-8699-3781

Matkovskiy Oleksandr Mykolajovych Leading concertmaster of the Department of Choreography and Musical and Instrumental Performance, Sumy State Pedagogical University named after A.S. Makarenko, 40000, Sumy, Romenskaya St., 87, tel.: (050) 807-06-93, https://orcid.org/0000-0001-7814-7991

\section{PRACTICE OF ORGANIZATION OF SUMMER DANCE CAMP: PSYCHOLOGICAL AND PEDAGOGICAL ASPECT}

Abstract. The article enlightens the features of organizing of summer dance camps. In the present-day digital era, when the physical activity among children decreased, the organization of their summer activities becomes utterly important. Thus, dancing camps gain more and more popularity, as they allow children to boost 
their physical activity, improve motor skills, and help in developing of mental activities when doing physical exercises.

The aim of the article is to show the peculiarities of organizing the summer dance camp. An important result of the study is that the terminological and conceptual apparatus is examined, in particular, the term "dancing camp" is defined as the temporary additional educational facility for children and teens, which purpose is mostly to help them acquire various dancing skills. It's mentioned, that summer dance camp pastime has many benefits, such as reoccurring creative activities, personal relationships, involvement in creative projects, intense recreation, integrated approach. Developed the forms of the work with the summer dance camp members, which are: dancing parties, rhythmic games, creative group activities, bonfire nights, competitions, dancing master classes, and training. Defined the main stages of the summer dance camp activity, namely: preparing, organizing, main stage, final stage, and the stage following the camp closure. Several entertainment programs of the summer dance camps were analyzed. The results are given as the list of the main forms of occupation, which are: distribution of the camp t-shirts, various dancing master classes, night entertainment programs, shooting a movie capturing every stage of dancing program or event, presenting of the dancing flash mob, meetings with the famous choreographers of the city, sports, and various competitions.

Keywords: dance camp, choreographer, master class, flash mob, entertainment program.

Постановка проблеми. Нині активний відпочинок у танцювальному таборі набирає все більше і більше популярності, оскільки він є установою, яка сприяє продовженню додаткової освіти дітей та є місцем їх самореалізації, самовираження, комунікації, підвищення самооцінки тощо. Літній танцювальний табір несе в собі життя в нестандартних умовах на чистому повітрі та найбільш ефективно готує дитину до дорослого життя й відповідальності.

Встановлено, що багато молодих і енергійних людей вважають за краще проводити свій вільний час з користю не тільки для розуму, але і для тіла. 3 огляду на це, саме танцювальне мистецтво допомагає у формуванні початкових математичних і логічних уявлень дитини, тренуванні навичок орієнтування в просторі. Заняття танцями розвивають образне мислення, фантазію та гнучкість, допомагають розвинути такі якості як організованість і працьовитість, збагачують руховий досвід, вдосконалюють моторику, розвивають активні розумові дії в процесі фізичних вправ. Навіть самі замкнуті діти стають більш розкутими, відкритими та товариськими. Отже, виникає нагальна потреба у вивченні практики організації літнього танцювального табору, оскільки його основною метою $\epsilon$ навчання вихованців як акторської майстерності, так і танцювального мистецтва, які в свою чергу розвивають пам'ять і сміливість у висловлюванні своїх емоцій. 
Журнал«Герстективита інновації наукиљ

(Серія «Гедагогіка», Серія «Геихологія», Серія «Медицин»

№(6) 2022

Аналіз останніх досліджень і публікацій. Аналіз наукових джерел показав, що проблема активного відпочинку дітей у літній період та організація їх діяльності була актуальною серед широкого загалу дослідників. У цьому зв'язку назвемо праці таких відомих теоретиків і практиків як М. Вайндорф-Сисоєва, О. Копитіна, М. Самойлова, Р. Круглікова, Р. Лінкер, В. Лаппо, О. Леванова, Т. Сахарова, М. Батаєва, Н. Галой, Р. Голишев та ін. Проблеми соціалізації підлітків стали предметом дисертаційних досліджень таких науковців, як I. Трубавіна, О. Шигаєва та ін. У межах мистецтва особливості роботи літнього табору досліджувалися А. Гаврилюком, В. Неретіним, Д. Неретіною, В. Рутецьким та ін.

Проте, аналіз джерел із проблеми дослідження довів, що питання стосовно організації діяльності літнього танцювального табору й досі не систематизовані та розроблені не в повному обсязі, що й становить актуальність нашого дослідження.

Мета статті - дослідження психолого-педагогічних аспектів організації літнього танцювального табору.

Виклад основного матеріалу. Нині, в умовах комп'ютерізації та зменшення рухової активності дітей, надзвичайно важливого значення набуває організація їх активного літнього відпочинку. Рішення цієї проблеми передбачає використання найновітніших методик щодо зайнятості дітей під час літніх канікул, яку частково вирішує організація відпочинку в танцювальному таборі. Таким чином, потребує визначення ключове поняття нашого дослідження «танцювальний табір», складові якого потрібно розглянути детальніше.

Не дивлячись на широке використання в науковій та популярній літературі поняття «танець», воно вимагає уточнення. Так, дане поняття у «Великому тлумачному словнику сучасної української мови» означає «вид мистецтва, у якому художній образ створюється пластичними та ритмічними рухами людського тіла» [1, С. 1430].

Загальний сенс категорії «танець» має своє специфічне наповнення у сполученні з терміном «табір». Так, поняття «табір» розглядається багатьма науковцями як тимчасовий багатопрофільний заклад додаткової освіти для дітей i підлітків, що створюється 3 метою забезпечення їх сезонного відпочинку [2, С. 5-6].

Таким чином, узагальнення означених міркувань дозволяє надати сутнісні характеристики одному з ключових термінів дослідження. Так, ми визначаємо поняття «танцювальний табір» як тимчасовий заклад додаткової освіти для дітей і підлітків, зміст діяльності якого переважно побудовано на оволодінні практичними навичками у різних танцювальних напрямках.

Зауважимо, що літній танцювальний табір є соціальним інститутом який сприяє природньому продовженню додаткової освіти дітей та формується на базі якої-небудь зареєстрованої дитячої організації. I відповідно, працює за планами, затвердженими в даній дитячій організації. Часто реалізується на базі 
заміського табору, може здійснюватися як повнофункціональний табір та як просто окрема табірна зміна. Характеризується відкритістю, мобільністю, гнучкістю, максимально орієнтується на запити і потреби дитини та соціуму в цілому. При цьому найбільш ефективними в діяльності оздоровчого табору є педагогічні технології саморозвитку, самореалізації, самоактивізації підлітка. Тут є контрольована програма для дітей і підлітків, що проводяться протягом літніх місяців. Це найпоширеніший спосіб організації активного дитячого відпочинку в період літніх канікул [2].

Специфіка роботи літнього танцювального табору полягає в тому, що під час цього періоду відбувається сепарації дітей від батьків, їх спілкування, нові знайомства, самостійність і відповідальність. Діти вчаться самі вирішувати свої проблеми, самі визначають і задовольняють свої потреби. Дитина, потрапляючи в новий колектив, проходить етап адаптації. За короткий час їй потрібно зайняти своє місце в загоні, знайти собі друзів і однодумців, визначити заняття до душі й подолати бар'єри спілкування та взаємодії. Саме тому, активний відпочинок у літньому танцювальному таборі вбирає в себе багато переваг, а саме: системотворчу роботу, міжособистісні стосунки, активну участь у творчій діяльності, інтенсивність роботи, комплексний підхід [3, С. 20].

Перейдемо до визначення мети та формулювання конкретних завдань організації літнього танцювального табору. Мета полягає у формуванні творчої особистості дитини за допомогою хореографічного мистецтва. Мета реалізується в ряді конкретних завдань: розвиток особистості кожної дитини, іiі танцювальних здібностей, індивідуальності; розвиток творчості як колективної, так й індивідуальної; навчання правилам i формам спільної роботи у галузі хореографії; реалізація комунікаційних потреб дітей тощо [4, С. 42].

Зазначимо, що дітям увесь період перебування в таборі тренер допомагає у набутті певних знань i вмінь 3 танцювального мистецтва та суспільнокорисних навичок загалом. Навантаження $є$ раціонально підібраним, з однієї сторони щоб діти сильно не втомлювались, а 3 іншої щоб воно сприяло успішному результату в їх роботі на будь-якому сценічному майданчику. Саме тому, діяльність літнього танцювального табору вбирає в себе різні форми роботи, до яких відносяться наступні [5]:

- вечори: танцювальні, зустрічі із видатними хореографами у різних жанрах, перегляд танцювальних відеофільмів тощо;

- ритмічні ігри: на знайомство, на згуртування колективу, сюжетні, рольові, рухливі, інтелектуальні тощо;

- колективно-творчі справи: рухові, дозвільні, інтелектуальні, трудові, 3 цілеспрямованим моральним змістом, по роботі з активом тощо;

- багаття: дружби, прощальний, одкровення;

- конкурси: танцювально-ритмічні змагання;

- танцювальні майстер-класи та тренінги.

Зауважимо, що специфіка діяльності літнього танцювального табору визначається, крім зазначених вище умов, також особливостями дитячого 
тимчасового об’єднання - короткочасністю його існування, автономністю, насиченістю та різноманіттям спілкування, відносинами та сумісною діяльністю, високою емоційною забарвленістю життєдіяльності тощо. А робота організатора такого танцювального табору має бути направлена на згуртування дітей, формування їх поважного ставлення один до одного, співпереживання [2, С. 21].

Перейдемо далі до розгляду основних періодів діяльності літнього танцювального табору. Так, у структурі організації й здійснення діяльності літнього танцювального табору дослідниці О. Копитіна, М. Самойлова, О. Леванова, Т. Сахарова, Г. Круглікова та ін. виділяють 5 періодів: підготовчий, організаційний, основний, заключний і посттабірний [2; 4; 6]. Розглянемо кожен з них детальніше.

1. Підготовчий період. На даному етапі відбувається продумування i побудова змісту табірної зміни, іiі основних форм роботи; підбираються певні методичні матеріали. Часто в даний період дитячі танцювальні табори проводять інструктивно-методичні збори, в яких майбутні тренери знайомляться $з$ територією табору і його програмою. У день заїзду на зміну здійснюється реєстрація, тренер складає список дітей в його загоні, розподіляє їх по кімнатах, інструктує щодо правил перебування в таборі тощо. Важливо на цьому етапі з'ясувати у батьків інформацію про здоров'я дитини: чи немає у неї алергії на якісь продукти, чи $є$ хронічні захворювання, чи були травми [4, С. 10-14].

2. Організаційний період. У перші три-чотири дні табірної зміни відбувається адаптація дітей. Важливо щоб тренер на цьому етапі організовував не менше десяти ігор на знайомство та згуртування колективу, а особливо знайшов підхід до кожної дитини та час на особистісне спілкування 3 ними [2, С. 17-19].

3. Основний період. Найдовший період табірної зміни під час якого відбувається самореалізація дитини в загоні й таборі. Тренер змінює свою позицію: від керівника і лідера він переходить на позицію консультанта й координатора. Змістом діяльності тренера в цей період виступає: організація та проведення дитячих масових свят, колективних творчих справ, концертів, ігор різної спрямованості згідно з планом-сітки роботи табору, загону; організація та проведення загонових вечірніх вогників різноманітної тематики; перегляд тематичних фільмів; поточна діагностика загонового колективу й особистості дітей [4, С. 16-17].

Зауважимо, що основний період зміни ділиться на два самостійні етапи: навчально-демонстраційний та демонстраційно-закріплювальний. Під час навчально-демонстраційного вирішуються такі завдання: оволодіння дитиною знаннями і вміннями відповідно до профілю програми, самовизначення у виборі видів діяльності, створення умов для прояву творчої індивідуальності кожної дитини, коригування ціннісно-мотиваційних норм спілкування та поведінки тощо. Під час демонстраційно-закріплювального етапу вирішуються 
наступні завдання: показ дитячих досягнень i надбань через різноманітні форми (ігрові програми, конкурси, турніри, спортивні змагання, танцювальні тренування), аналіз індивідуальних i групових дій спрямованих на стимулювання успішності учасників програми в різноманітних видах діяльності [4, С. 17-19].

4. Заключний період. Відбувається підведення підсумків за останні

3-4 дні зміни. Діти з'ясовують, чому вони навчилися, який досвід вони придбали. Основними завданнями тренера у цей період танцювальної зміни є: аналіз i демонстрація індивідуальних i групових досягнень; створення емоційної атмосфери успішного завершення зміни, нагородження грамотою найбільш активних дітей в команді; організація справ, що знімають психологічне напруження щодо тимчасовості перебування, викликане швидким від’іздом; діагностика i розробка індивідуальних програм саморозвитку. Означені завдання можуть вирішити наступні форми роботи: підсумковий збір загону, прощальний «Вогник», прощальна «Свічка», перегляд відео які були зняті протягом танцювальної зміни тощо [4, С. 19-21].

5. Посттабірний період. Настає після закінчення зміни, коли діти повертаються додому. На даному етапі відбувається аналіз діяльності в танцювальному таборі. Дитина формує ставлення до життя в таборі та бажання або небажання провести наступні літні канікули в дитячому танцювальному таборі. Тренер здійснює педагогічний аналіз своєї діяльності та знаходить відповіді на питання: «Що вийшло?», «Що не вийшло?», «Чому?» [4, С. 21-22].

Зауважимо, що діяльність літнього танцювального табору обмежується певними рамками (організаційними, творчими, психофізіологічними, віковими тощо), ознайомившись зі специфічними особливостями яких можна приступати до розроблення розважальної програми. Так, проаналізувавши декілька розважальних програм літніх танцювальних таборів (D.M.F., STAR TIME CAMP, Танцювальний табір 2021) [7; 8; 9] вважаємо, що представити результати варто у вигляді переліку основних форм діяльності, а саме:

- роздача фірмових футболок табору (на яких усі запрошені хореографи лишатимуть власний автограф);

- майстер-класи з різних напрямів: hip-hop, jazz funk, dancehall, vogue, contemporary, повітряна акробатика (танець на полотнах), балет, народні танці, бальні танці, східні танці, акторська майстерність тощо;

- вечірні розважальні програми: «Світлофор», «Рухливий морський бій», «Ліпсінк батл» (шоу зіркових пародій), «День Нептуна», «Кінозал просто неба», «Зйомка відео-кліпу», «White fashion», «Святковий концерт», «Прощальне багаття» тощо;

- зйомки відеоролику 3 усіма моментами танцювальної зміни для TikTok, Instagram, YouTube;

- вивчення та презентація танцювального флешмобу;

- фан-зустрічі з навідомішими хореографами міста;

- спортивна програма та змагання з усіх видів спорту. 
Журнал«Герспективитаіновації наукиљ

(Серія«Гедагогіка», Серія«ГЕихологія», Серія«Медицинв»

№1(6) 2022

Таким чином, аналіз розважальних програм літніх танцювальних таборів показав, його учасники мають величезну можливість не тільки брати в них пасивну участь, а й проявляти свої творчі, інтелектуальні, спортивні та інші здібності. Розглянемо далі специфіку перелічених вище форм діяльності більш детальніше.

Слід наголосити, що кожного дня на дітей повинна чекати спортивна програма на свіжому повітрі. Така форма роботи, зазвичай, має назву «бадьора стежка» - це стежка де на кожному наступному метрі лежать гілочки, шишки, каміння, кора дерев, пісок, сіль, звичайна трава тощо. Ця стежка виступає масажором для ніг, який дозволяє підняти загальний тонус, а також поліпшити кровообіг у всьому організмі. Після проходу означеної стежки діти відчувають піднесеність настрою і легкість при русі. Це пояснюється тим, що при впливі на стопи людини відбувається стимуляція точок, пов'язаних з внутрішніми органами, за рахунок чого стимулюється їх активна діяльність як у мистецькій сфері, так і в танцювальній зокрема. Після стежки вкрай важливо здійснювати пробіжку на свіжому повітрі, силові тренування та вправи з аквааеробіки, які у дітей розвивають витривалість і спритність, покращують мінеральну щільність кісток, сприяють регуляції рівня холестерину в крові та підтримку нормальної маси тіла [10, С. 102-103].

Обов'язково кожного дня здійснюються тренування в танцювальному залі з дзеркалами, під час яких діти вивчають нові стилі танцю, такі як hip-hop, jazz funk, dancehall, vogue, contemporary або отримують творчі завдання, а саме: за 30 хвилин придумати зв'язку із декількох рухів під музику, після закінчення відведеного часу кожен виходить та демонструє свій етюд. Така форма роботи допомагає в розвитку творчих здібностей та фізичного вивільнення.

Часто проводять 3 дітьми розважальну програму «ліпсінк батл» - це таке шоу зіркових пародій, завданням якого є: сліпе витягування імені відомого хореографа та його танцювального стилю; підготовка та пародіювання манери поведінки обраного під час виступу; демонстрування танцювальної комбінації під отриману музичну композицію. Часто «ліпсінк батл» поєднують 3 танцювальними майстер-класами цих самих хореографів, які тривають 2-3 години, після чого діти фотографуються на пам'ять та знімають танцювальні відео.

Наголосимо на тому, що важливою формою роботи в літньому танцювальному таборі $є$ перегляд танцювальних відео команд 3 високим професійним рівнем або художніх фільмів хореографічного спрямування. Оскільки це надихає учасників на подальше розкриття своїх талантів та плідну роботу з метою особистого розвитку в цій сфері.

У кінці танцювальної табірної зміни, має відбутися святковий концерт, де всі учасники презентуватимуть флешмоби, танці з різних напрямів, сценки тощо. Після чого важливо провести «прощальне багаття» та перегляд змонтованого відеоролику з усіма моментами танцювальної зміни.

Отже, розважальні програми літніх танцювальних таборів досить насичені 
великою кількістю заходів і виступів, в яких діти беруть безпосередню участь. Також у таборах має бути вся необхідна інфраструктура для занять танцювальним мистецтвом, зокрема: танц-класи, велика сцена актового залу, танцювальні майданчики на вулиці, літня естрада, майданчик зі штучним покриттям, «бадьора стежка», пляж табору на березі річки тощо.

Висновки. Результати проведеного дослідження дозволяють визначити важливість висвітлення практики організації літнього танцювального табору та дійти таких висновків:

1. Конкретизовано та уточнено термін «танцювальний табір» яке розуміємо як тимчасовий заклад додаткової освіти для дітей і підлітків, зміст діяльності якого переважно побудовано на оволодінні практичними навичками у різних танцювальних напрямках.

2. Розкрито специфіку діяльності літнього танцювального табору. Зазначено, що активний відпочинок у таборі вбирає в себе багато переваг, зокрема таких як: системотворчу роботу, міжособистісні стосунки, активну участь у творчій діяльності, інтенсивність роботи, комплексний підхід. Виділено форми роботи з учасниками літнього танцювального табору, до яких відносяться наступні: вечори, ритмічні ігри, колективно-творчі справи, багаття, конкурси, танцювальні майстер-класи та тренінги. 3'ясовано основні періоди діяльності літнього танцювального табору, а саме: підготовчий, організаційний, основний, заключний та посттабірний періоди.

3. Проаналізовано декілька розважальних програм літніх танцювальних таборів. Результати представлено у вигляді переліку основних форм діяльності, до яких відносяться: роздача фірмових футболок табору, майстеркласи з різних танцювальних напрямів, вечірні розважальні програми, зйомки відеоролику з усіма моментами танцювальної зміни, вивчення та презентація танцювального флешмобу, фан-зустрічі з найвідомішими хореографами міста, спортивна програма та змагання з усіх видів спорту.

Подальшу перспективу дослідження вбачаємо в розробленні комплексу танцювальних вправ та завдань для здійснення діяльності в літньому танцювальному таборі.

\section{Лimepamypa:}

1. Бусел В. Т. Великий тлумачний словник сучасної української мови. Київ, Ірпінь : ВТФ «Перун», 2005. 1728 c.

2. Кругликова Г. Г., Линкер Г. Р. Теория и методика организации летнего отдыха детей и подростков : учебное пособие. Нижневартовск : Изд-во Нижневарт. гуманит. ун-та, 2011. 236 с.

3. Лаппо В. В. Методика виховної роботи в літніх дитячих оздоровчих таборах : практичний посібник. Івано-Франківськ : НАР, 2016. 306 с.

4. Леванова Е. А., Сахарова Т. Н., Батаева М. Д., Галой Н. Ю., Голышев Г. С. Организация массовых мероприятий в детском оздоровительном лагере : методические рекомендации / под общей редакцией Е. А. Левановой, Т. Н. Сахаровой. Москва : МПГУ, 2017. $212 \mathrm{c}$.

5. Вайндорф-Сысоева М. Е. Организация летнего отдыха детей и подростков : учеб. пособие для прикладного бакалавриата. Москва : Издательство Юрайт, 2016. 160 с. 
6. Копытина О. И., Самойлова М. Н. Организация работы в оздоровительном лагере: теория и методика : учебно-методическое пособие. Курган : Курганский государственный университет, 2011. 115 с.

7. Літній розвиваючий табір «STAR TIME CAMP». URL: https://elitatour.com.ua/catalog/letnij-razvivayushhij-lager-star-time/ (дата звернення: 10.01.2022).

8. Танцювальний табір 2021. URL: https://kidsvisitor.com/uk/lviv/camp/1985tantsiuvalnii-tabir-2021/ (дата звернення: 10.01.2022).

9. Танцювальний табір D.M.F. URL: https://ternopil.dityvmisti.ua/shkola-tantsyu-dancemafia-family/tantsyuvalnij-tabir-d-m-f-dance-mooves-forever/ (дата звернення: 10.01.2022).

10. Трубавіна I. М. Проблеми і шляхи підготовки майбутніх педагогів до роботи в дитячих оздоровчих таборах. Педагогіка, психологія та медико-біологічні проблеми фізичного виховання і спорту. 2010. № 9. С. 102-104.

\section{References:}

1. Busel, V. T. (2005). Velykyj tlumachnyj slovnyk suchasnoi ukrains'koi movy [Large explanatory dictionary of the modern Ukrainian language]. Kyiv, Irpin': VTF «Perun» [in Ukrainian].

2. Kruglikova, G. G., \& Linker, G. R. (2011). Teoriia i metodika organizatsii letnego otdykha detei i podrostkov [Theory and methods of organizing summer vacations for children and adolescents]. Nizhnevartovsk: Izd-vo Nizhnevart. gumanit. un-ta [in Russian].

3. Lappo, V. V. (2016). Metodyka vykhovnoi roboty $v$ litnikh dytiachykh ozdorovchykh taborakh [Methods of educational work in summer children's health camps]. Ivano-Frankivs'k: NAR [in Ukrainian].

4. Levanova, E. A., Sakharova, T. N., Bataeva, M. D., Galoi, N. Iu., \& Golyshev, G. S. (Ed.). (2017). Organizatsiia massovykh meropriiatii $v$ detskom ozdorovitel'nom lagere [Organization of mass events in a children's health camp]. Moskva: MPGU [in Russian].

5. Vaindorf-Sysoeva, M. E. (2016). Organizatsiia letnego otdykha detei i podrostkov [Organization of summer vacations for children and adolescents]. Moskva: Izdatel'stvo Iurait [in Russian].

6. Kopytina, O. I., \& Samoilova, M. N. (2011). Organizatsiia raboty v ozdorovitel'nom lagere: teoriia $i$ metodika [Organization of work in a health camp: theory and methodology]. Kurgan: Kurganskii gosudarstvennyi universitet [in Russian].

7. Litnij rozvyvaiuchyj tabir «STAR TIME CAMP» [Summer Development Camp «STAR TIME CAMP»]. Retrieved from https://elitatour.com.ua/catalog/letnij-razvivayushhij-lager-startime/ [in Ukrainian].

8. Tantsiuval'nyj tabir 2021 [Dance camp 2021]. Retrieved from https://kidsvisitor.com/uk/lviv/camp/1985-tantsiuvalnii-tabir-2021/ [in Ukrainian].

9. Tantsiuval'nyj tabir D.M.F. [Dance camp D.M.F.]. Retrieved from https://ternopil.dityvmisti.ua/shkola-tantsyu-dance-mafia-family/tantsyuvalnij-tabir-d-m-f-dancemooves-forever/ [in Ukrainian].

10. Trubavina, I. M. (2010). Problemy i shliakhy pidhotovky majbutnikh pedahohiv do roboty $\mathrm{v}$ dytiachykh ozdorovchykh taborakh [Problems and ways of preparation of future teachers to work in child's health camps]. Pedahohika, psykholohiia ta medyko-biolohichni problemy fizychnoho vykhovannia i sportu [Pedagogy, psychology and medical and biological problems of physical education and sports], 9, 102-104. 